\title{
Structural changes and productivity in Latin American industry, 1970-1996
}

\section{Jorge Katz}

Director,

Division of Production,

Productivity and Management, ECLAC

jkatz@eclac.cl
This article analyses the structural changes in Latin American industry, which speeded up in the 1990s with the consolidation in the region of the external openness programmes, the deregulation of many markets, and the privatization of major sectors of industrial activity which had previously been dominated by State enterprises. The branches of manufacturing which have turned in the best relative performances over the last twenty years are natural resource-based industries producing staple industrial commodities, industries assembling computers, video equipment, television sets or clothing, and the motor industry, which has been given preferential treatment in government economic policy. In contrast, industries producing labour-intensive final goods, those making intensive use of technological knowledge and new product design engineering, or those producing heavy capital goods have been losing relative weight. The pattern of production specialization and the places occupied in world markets for manufactures have clearly been changing, with greater emphasis on utilization of the natural comparative advantages of the region (i.e., its abundant natural resources) or on sectors which have been given special treatment in industrial policy. The article explores the behaviour of the Latin American industrial structure in terms of productivity, comparing it with that of the developed countries. Using the case of the United States as a reference universe, it estimates the labour productivity gap with respect to that country and evaluates the performance of countries and industrial branches in the region as a function of that parameter. 


\section{A general overview}

In previous studies I already addressed the big changes undergone by the Latin American industrial structure in the 1980s and 1990s ${ }^{1}$. It is clear from those studies that that process of structural change speeded up in the 1990s with the consolidation in the region of the external openness programmes, the deregulation of many markets, and the privatization of major sectors of industrial activity which had previously been dominated by State enterprises. Although the studies in question do not analyse the details of each national case, they clearly show that two clearly differentiated patterns of production specialization and insertion in the world markets for manufactures have been growing up in the region. On the one hand, in the southern part of the region, and especially in Argentina, Chile, Brazil and Uruguay, the natural resource-based industries producing staple industrial commodities (such as iron and steel, petrochemical products, non-ferrous minerals, fish meal, vegetable oils, pulp and paper, etc.) have turned in a better relative performance over the last twenty years. On the other hand, in Mexico and the smaller Central American countries the pattern of production specialization has decisively favoured assembly industries (such as those assembling, computers, video equipment, television sets and clothing).

In the first case, the industrial branches in question produce highly standardized intermediate goods for which great locally-owned conglomerates -together with a small number of foreign corporations- have installed extremely modern capital-intensive processing plants using process technologies matching up to the best international levels. On the basis of such plants, the countries in question have turned themselves within the space of only a few years into major exporters of industrial commodities, which they sell on highly competitive markets where the Latin American firms act as pricetakers, have little bargaining power, and have only small unit profit margins.

$\square$ This article forms part of the research project entitled"Growth, employment and equity. The impact of the economic reforms in Latin America and the Caribbean", carried out by ECLAC and by researchers from nine countries of the region and financed by the governments of the Netherlands and Sweden, the Canadian International Development Research Centre, and the Ford Foundation.

${ }^{1}$ See Katz (1997) and Katz, Benavente, Crespi and Stumpo (1997).
In the second case -that of assembly industries- the assembly plants are also extremely modern and close to the best international levels of the industry, operate in accordance with complex "just in time" production logistics, and are essentially designed to supply the United States market. In this case, the main comparative advantage is the low real wages paid in the countries of the region, which make it possible to successfully compete with Japan and South Korea in the United States domestic market.

In contrast with the above two cases, there has been a decline in the relative position occupied in manufacturing by industries producing labour-intensive final goods (footwear, clothing, etc.) and those that make intensive use of technological knowledge and new product design engineering to produce such items as capital goods, pharmaceutical and chemical inputs and scientific instruments. In the case of labour-intensive goods, the opening-up and deregulation of the region's economies have meant that they must compete with similar goods from countries where wages are much lower (such as China), while knowledge-intensive goods have not been able to compete in areas of production where technological obsolescence is rapid and goods have a short useful life but demand heavy outlays on technological research. At the international level, these industrial sectors have been rapidly incorporating both the use of microprocessors, digitalization and numerical control and new types of knowledge based on genetics and biotechnology: all fields where the relative backwardness of Latin American firms has become more marked in recent years, so that their international competitiveness has gone down even further.

The motor industry, for its part, has enjoyed special tariff and fiscal treatment both in the Southern Cone countries and those around the Gulf of Mexico. This industry has also made significant progress in technological modernization and has come to have greater relative weight within the production structure.

We have seen that the pattern of production specialization and the form of insertion in world markets for manufactures have favoured highly capital-intensive industries, such as those exploiting the natural comparative advantages of the region (its abundant forestry, fishery, oil, gas, mineral and tourist resources), or else 
labour-intensive sectors which, as in the case of the assembly industries, reflect the global competitive strategies of some of the major transnational corporations which have decided to develop a big export platform in the area around the Gulf of Mexico. This "new" pattern of production and trade specialization has many pros and cons -for example, as regards the generation of new jobs and its impact on the external accounts of the economybut these will not be dealt with in particular in the present article.

The above-mentioned changes have been taking place side by side with equally complex changes in the morphology, behaviour and relative weight of the different branches of production within each individual economy. Profound changes are taking place both in the regulatory and institutional framework of each sector of production (including rights of ownership over natural resources, patent legislation, and labour laws) and in the sets of actors participating in the process of structural change. Many firms have moved out of the market, there have been innumerable purchases and mergers of enterprises, and those which have managed to survive have been undergoing marked changes in the organization and planning of their production, their market strategies, and their technological and international marketing capabilities. The new production organization models display less vertical integration (that is to say, they involve more local and international subcontracting) and they are more conditioned by the external environment, as many firms now work "on line" with their international technology suppliers and process licensors and hence make use of fewer local engineering efforts.

This process, which began to take shape in the 1980s, in the midst of the external debt crisis and the slowdown in domestic market-based growth, gathered momentum in the 1990s in line with the increasingly competitive climate in the countries of the region and with the consolidation of a new structure of relative prices in each economy. This structure may be considered as being closer to the "true" opportunity cost of the domestic resources used than the structure that prevailed during the import substitution period and, in this respect, less likely to favour the use of local technological capabilities.

This process led to a major change in the sources and nature of the technological changes that the various sectors of production were incorporating. Technological advances of outside origin and private expenditure on research and development came to predominate over domestic efforts. Whereas the import substitution model had promoted the local production of capital goods and the use of technologies and engineering services of do- mestic origin, the opening up of the economies to the exterior made imported capital goods cheaper and made it easier to obtain licences and technical assistance from abroad: a situation which became still more marked with the strengthening of intellectual property rights, which increased the propensity of the local agents of production to fill their needs with equipment and technology from the developed countries and the interest of foreign firms in licensing their products and production technologies.

As a result, foreign direct investment flows have significantly increased in the areas of both manufacturing and services and have been an important means of access to new technologies in the fields of products, processes and organization of production. Outstanding among the new foreign players who have entered on the regional scene in recent years are some big firms with extensive experience which were generally public enterprises in their home countries, where they operated in such fields as telecommunications, energy, transport, water supply, etc. Their incorporation into the local production environment has been accompanied by technological modernization processes and improvements in productivity, both in the areas in which they themselves operate and in the sectors using their services (i.e., upstream and downstream of their place in the production structure). On the other hand, the labour-saving bias implicit in the new technologies has become still more marked, thus influencing the industrial sector's growing difficulty in generating new jobs in line with the growth of the economically active population.

In addition to the foregoing, it may be noted that the external trade balance of the new manufacturing sector has been becoming increasingly negative because of the growing weight of imports of machinery and production equipment, vehicles, and items in the area of electromechanics and electronics, in contrast with the slower growth rate of exports of industrial commodities.

This concludes our very brief description of past developments. We shall now see how this "new" structure of production has performed in terms of labour productivity, and especially, how it has performed in comparison with the developed world, using the United States as a "reference universe" against which to weigh the performance of the countries and industries of the region.

The ideal situation would be to work with indicators of total productivity: i.e., the whole set of production factors used in the economy. Because of the absence of data on gross capital formation at the level of industrial branches, however, we have opted to concentrate 
on what occurred in the area of labour productivity. The information presented here corresponds to nine countries of the region and 27 industrial branches, defined at the three-digit level of the International Standard Industrial Classification (ISIC) for the period from 1970 to 1996. We will give special attention to the 1990-1996 stage, since those years witnessed an increase in the efforts at external openness, deregulation and privatization of economic activities in the various countries of the region. We will begin at the aggregate level -that is to say, analysing the evolution of labour productivity for manufacturing as a whole in each country- and then go on to analyse the different sectoral situations in order to identify differences between the performance patterns of the different countries and industrial branches, as compared with the "reference universe".

As we shall see below, the data show that behaviour was heterogeneous both between countries and between branches of activity. Some countries and industrial branches show clear signs of coming closer to the labour productivity of the United States, whereas others have markedly lost ground.

In section II below we will present the basic estimators obtained in the course of this study, while in section III we will seek to find a possible explanation for what happened. This leads us to the study of the behaviour of the agents of production, the changes in this behaviour over time, and the historical and institutional context in which the agents have acted.

The current literature offers various different approaches to the study of the factors determining improvements in factor productivity. On the one hand, there are explanations of a neoclassical nature expressed through "growth accounting", based on the contributions of R. Solow and others in the 1950s (Solow, 1957) and liberally re-used by economists more recently in the context of modern growth theory (see for example Barro and Sala-i-Martin (1996) and Rommer (1986 and 1992)).

In these authors, the analysis is based on conventional neoclassical assumptions of perfect information, fully specified generic production functions, "well-behaved" firms, equilibrium paths, perfectly competitive markets, and factors paid according to their marginal productivity.

In this type of conceptual framework, the explanation of how productivity grows with time is extremely stylized and does not allow of any differences of behaviour between firms in the same sector, does not offer any opportunity for the discussion of alternative business strategies in the context of a given set of exogenous data, and does not allow for the presence of mar- ket failures or different processes of accumulation of experience and learning by firms in a given branch of production. The model is an extremely simple specification of microeconomic behaviour, the operation of the markets, and the long-term growth of a given society. In this stylized version, historical and institutional variables play almost no part, except through their influence on relative factor prices (Katz and Kosacoff, 1998). It is precisely this drastic simplification of real conditions, with the elimination of all market imperfections, of the uncertainty and asymmetrical information that can affect the behaviour of economic agents, and of the differences between generations as regards their propensity to save and consume (Solow, 1988), which makes it desirable to add individual equilibrium forms of behaviour in order to obtain macroeconomic investment, production or consumption functions with which to describe the aggregate behaviour of the economy.

Modern studies on growth theory, however, incorporate the possibility of increasing returns to scale and externalities at the branch level, without this involving any contradictions with the basic logic of the competition model, since it is possible to continue assuming that each agent complies of his own free will with the basic requisites of the behaviour model, but there are also circumstances foreign to each particular agent to which the existence of increasing returns to scale and externalities may be attributed. Even so, the institutional complexities and the question of uncertainty underlying the behaviour of enterprises in terms of technology and innovation are still not properly identified by the theory, as shown in various recent studies by "evolutionist" authors such as Nelson (1997).

However, in the course of the last two decades a number of economists (following a different analytical path from that referred to above) have tried to explore the issues of innovation and productivity in a different conceptual framework of a more classical and evolutionary nature (Nelson and Winter, 1982; Dosi (ed.), 1988; Freeman, 1994, and Metcalfe, 1997, among others). These authors seek to explain improvements in productivity not only as the result of forms of behaviour that maximize equilibrium, but also as the consequence of a process of "natural selection" in which competition plays a crucial role. The success or failure of different enterprises, imperfect information, uncertainty, and differences in strategy between enterprises competing in the same market are central features of a long-term process of "purification" involving both "mutations" of an almost genetic nature (Nelson, 1997) and historical, cultural and institutional factors -genotypes and fenotypes, 
in Nelson's "biological" language- which shape the path of productivity growth over time. Here, growth is not seen as the result of equilibrium-based forms of behaviour but forms a "cultural construct" allowing of more Schumpeterian-type processes of "creative destruction" which, by definition, goes beyond the static Paretian framework of the conventional neoclassical model. The explanatory mechanism has a historical and institutional background, a basic substrate of uncertainty and market flaws, which does not fit into the neoclassical metaphor. Whereas the latter is firmly rooted in conventional price theory, the "evolutionary" analytical discourse has a large component of "cultural anthropology" which goes far beyond the ambit of our typical textbook microeconomics.

The entry and exit of firms from the market, mergers, changes in strategy by firms, and the gradual changes taking place in what we will call here the "sectoral competitive regime" are key elements for understanding the reasons why the average productivity of a sector of production improves over time. The historical and institutional context plays a central role, conditioning what the agents of production want to do, know how to do and can do, unlike the context of the neoclassical model, in which those agents always know everything they need to know and are perfectly aware of what they should do. In this latter context, forms of conduct are automatic responses to a given set of exogenous data. In the firstnamed context, however, they are "adaptative": that is to say, they are based on trial and error, and competition acts as a "selection mechanism" which rewards certain decisions and punishes others.

The present study comes within this latter analytical field and seeks to study the changes undergone by labour productivity in Latin American industry in the context of the structural changes and changes in patterns of specialization referred to earlier: that is to say, in the context of the changes towards industries processing natural resources, assembly industries, and sectors -such as the motor industry- which have managed to obtain preferential forms of treatment from the economic authorities which have protected them from the otherwise across-the-board openness of the economy to the exterior.

In particular, we are interested in analysing the evolution of labour productivity in industry in the 1990s and the differences registered in the various countries and industrial branches in this respect compared with the past: that is to say, compared with the import substitution stage.

Throughout this study, the analysis will be essentially at the meso-economic level, to which end we will examine a set of inter-temporal and cross-sectional esti- mates of industrial activity at the three-digit level of aggregation. This will enable us to offer a first explanatory hypothesis of what happened over the 1970-1996 period and of the rising trend in labour productivity in the region -although not in every one of the countries or every one of the industries- in the 1990s. We believe that although this analysis at the meso-economic level is useful and necessary, it is not of itself sufficient: it is only the first step in an explanatory chain which must necessarily be continued at the level of the individual firms, although for reasons of space this will not be possible in this study. It seems to us to be essential to progress towards a more complex and detailed level of explanation which will help us to understand, for example, the role played by various big domestic economic groups and also various transnational corporations in the different countries. Ultimately, this will enable us to understand the reasons for the different long-term performances of the countries of the region and the particular features of the process of restructuring of production which have been taking shape in each case after the recent efforts at greater external trade openness and market deregulation.

The sectors of production which have shown the greatest capacity to survive in this external openness process are those which come closest to the static comparative advantages of each economy, and also those which, through political lobbying, have secured special treatment from governments (such as the motor industry or assembly industries). In these sectors, levels of investment were maintained even against the background of the severe drop in aggregate investment in the 1980s. This led to the formation of a new pattern of production specialization and new forms of insertion in the world markets for manufactures which emphasize the production of highly standardized industrial commodities and a few branches of light industry (assembly activities) in which various transnational corporations have played a leading role as sources of the new product designs, new process technologies and international marketing channels which have allowed a number of countries of the region to compete on developed country markets.

Our explanatory hypothesis suggests that the new pattern of production specialization of the countries of the region has been determined by their static comparative advantages, the lingering effects of the industrial policies applied in the import substitution period and, finally, by the strategies of a few big transnational corporations which have decided to use a number of countries located around the Gulf of Mexico as export platforms to the United States market. 
II

\section{Evolution of labour productivity in}

\section{Latin American industry, 1970-1996}

This section gives estimates of the growth rates of Latin American labour productivity, first for the manufacturing sector as a whole in nine countries of the region, and then for 27 industrial branches (at the three-digit ISIC level) in five countries: Argentina, Brazil, Chile, Colombia and Mexico. In the calculations we will use the $\mathrm{PADI}^{2}$ data base, which includes series for value added at current and constant prices, employment, wages paid, labour productivity (measured as value added per man/year), unit labour costs and gross unit margins, for the period from 1970 to 1996. On the basis of this information it is possible to make some previously non-existent comparisons of labour productivity between countries of the region and between them and the United States.

\section{Labour productivity in the industrial sector}

We will begin by presenting labour productivity indicators for the manufacturing sector as a whole in nine countries of the region and the United States, first covering the period from 1970 to 1996 and then the 1990-1996 stage, when there were clear indications of a significant speeding-up of the growth rate of the product per person employed in several of the countries examined. For the period as a whole (i.e., 1970-1996), we see that only three countries of the region (Argentina, Colombia and Mexico) attained growth rates of labour productivity in industry higher than those registered in the United States manufacturing sector (table 1).

This indicates that, although in absolute terms the distance is still large, the relative labour productivity gap in manufacturing between those three countries and the United States has tended to narrow: after starting in the 1970s from absolute levels which were only about $30 \%$ of average United States industrial labour productivity (even less in the case of Colombia), we see that by the end of the period Argentine industry had almost doubled its productivity, while Colombia and Mexico registered somewhat smaller but nevertheless significant improvements (table 2).

\footnotetext{
2 Prepared recently by the ECLAC Division of Production, Productivity and Management. I should like to express my thanks to Giovanni Stumpo for the efforts made in this respect and for his cooperation in giving me free access to this data base.
}

Of the other countries studied, Brazil registered substantial improvements in the growth rate of labour productivity between 1990 and 1996, although it had made little progress in closing the relative labour productivity gap in the previous two decades. In the five remaining countries (Chile, Costa Rica, Jamaica, Peru and Uruguay) this gap has either remained more or less constant or even tended to widen. Although Chile doubled the growth rate of its industrial labour productivity after opening up its economy, its position over the period as a whole remained more or less static, without much change in comparison with its initial situation. Peru, Uruguay and Jamaica, for their part, clearly lost ground in terms of labour productivity compared with the United States.

\section{Labour productivity by branches of manufactur- ing in Argentina, Brazil, Chile, Colombia and Mexico}

The fact that the relative gap in manufacturing labour productivity narrowed somewhat in Argentina, Brazil, Colombia and Mexico at the aggregate level does not mean, of course, that the performance in this respect was the same in each and every one of their industrial branches. In order to analyse the differences in behaviour between industrial branches in greater detail for these five countries, we made identical estimates of their relative labour productivity compared with similar branches in the United States, at the three-digit level of the ISIC (table 3).

A coefficient greater than one indicates that the industrial branch in question tended to narrow the relative labour productivity gap with the corresponding branch in the United States between the base year (1976) and the last year in the series studied. It also gives an indication of the extent to which the gap was reduced. A coefficient of less than one indicates a relative setback in this field. As we can see, there is a great deal of heterogeneity both between branches in the same country and between countries.

This information shows us, for example, that in $\mathrm{Ar}$ gentina 12 branches displayed what we might call a "successful performance" which allowed them to significantly 
Latin America (nine countries) and United States: Labour productivity indicators in manufacturing, 1970-1996 and 1990-1996

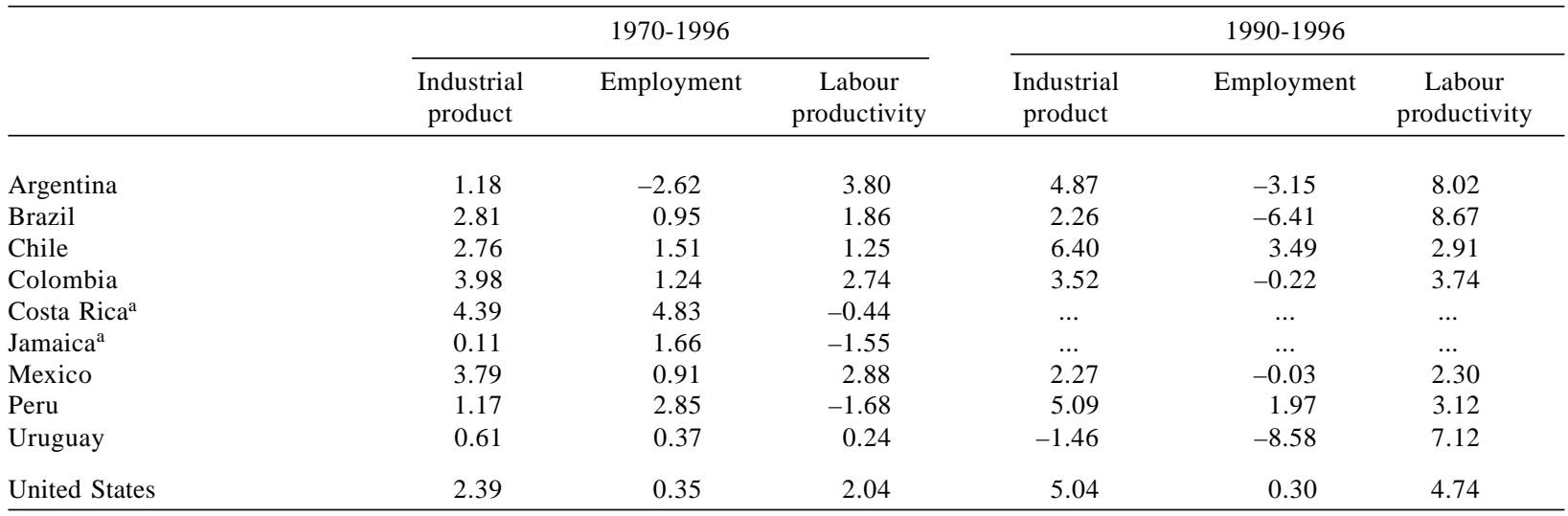

Source: PADI data base of the ECLAC Division of Production, Productivity and Management.

${ }^{a}$ Data only up to 1992.

TABLE 2

Latin America (nine countries): Evolution of the relative labour productivity gap in manufacturing between Latin America and the United States (Manufactures as a whole) $(U S=1.00)$

\begin{tabular}{lcccc}
\hline Country & 1970 & 1980 & 1990 & 1996 \\
\hline Argentina & 0.42 & 0.41 & 0.55 & 0.67 \\
Brazil & 0.28 & 0.26 & 0.29 & 0.37 \\
Chile $^{\mathrm{a}}$ & 0.25 & 0.24 & 0.23 & 0.20 \\
Colombia $^{\mathrm{b}}$ & 0.29 & 0.25 & 0.37 & 0.34 \\
Costa Rica $^{\mathrm{b}}$ & - & - & 0.15 & 0.14 \\
Jamaica $^{\mathrm{b}}$ & 0.26 & 0.16 & 0.16 & 0.13 \\
Mexico $^{\mathrm{c}}$ & 0.32 & 0.30 & 0.44 & 0.38 \\
Peru $_{\text {Uruguay }}^{\mathrm{a}}$ & 0.33 & 0.25 & 0.16 & 0.15 \\
\hline
\end{tabular}

Source: PADI data base.

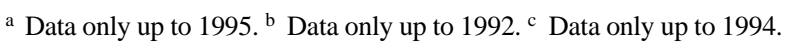

narrow the relative labour productivity gap with the United States. We consider as a "successful performance" a coefficient close to or greater than 2 , which would give the branch in question a relative labour productivity indicator at the end of the period which was approximately double that of 1970. There were seven such branches in Brazil, five in Colombia, but only three in Chile.

If we look at particular branches rather than countries as a whole, we can see, for example, that in the case of branch 384 (transport equipment) Argentina and Colombia register large relative improvements in labour productivity, Brazil showed more modest gains, and Chile registered a clear setback. In branch 371 (iron and steel) Argentina, Colombia and Brazil register extremely pro- nounced improvements in their relative position (Argentina even surpassed average United States productivity at the end of the period), whereas although Chile and Mexico did make advances, these were much less spectacular than in the first three countries.

Behind each of these sectoral situations there is a particular market morphology, a specific regulatory and institutional situation, and different competition strategies between firms which make up what we will call a special "system of competition and innovation" for each sector and country. It is essential to understand how this system works in each country, and how it differs between countries and industrial branches, in order to gain an idea of how the Latin American production apparatus has been gradually restructured. Although such a study is outside the scope of this article, it is important to note that the results presented here should be complemented in the future with detailed studies of the various sectoral systems of competition and innovation in order to gain a better understanding of what has happened in Latin American industry in the last two decades.

\section{The increase in the growth rate of labour pro- ductivity in the 1990s}

Except in the case of Mexico, where the growth rate of labour productivity in the 1990s was lower than that of the 1970-1996 period as a whole, table 1 shows that there was a considerable increase in this growth rate in all the other countries studied, including the United States. However, the figures also reflect the growing inability of the industrial sector in the various Latin American 
Latin America (five countries): Labour productivity gap

of Latin American industrial branches compared

with similar branches in the United States, 1970-1996

(27 industrial branches)

\begin{tabular}{|c|c|c|c|c|c|c|}
\hline \multicolumn{2}{|c|}{ ISIC group } & \multirow{2}{*}{$\frac{\text { Argentina }}{1.10}$} & \multirow{2}{*}{$\begin{array}{r}\text { Brazil } \\
1.14\end{array}$} & \multirow{2}{*}{$\begin{array}{c}\text { Chile }^{\mathrm{a}} \\
0.67\end{array}$} & \multirow{2}{*}{$\frac{\text { Colombia }}{0.93}$} & \multirow{2}{*}{$\frac{\text { Mexico }^{b}}{1.21}$} \\
\hline 311 & Food & & & & & \\
\hline 313 & Beverages & 1.04 & 0.72 & 0.91 & 0.79 & 0.83 \\
\hline 314 & Tobacco & 0.74 & 0.21 & 0.76 & 0.28 & 0.38 \\
\hline 321 & Textiles & 1.67 & 1.43 & 0.77 & 1.23 & 0.75 \\
\hline 322 & Clothing & 1.17 & 1.20 & 0.75 & 1.30 & 1.85 \\
\hline 323 & Leather and leather products & 1.38 & 0.93 & 0.45 & 0.58 & 0.97 \\
\hline 324 & Footwear & 0.78 & 1.13 & 0.65 & 1.03 & 0.72 \\
\hline 331 & Wood and wood products & 0.55 & 0.87 & 0.97 & 0.94 & 0.94 \\
\hline 332 & Furniture & 2.69 & 1.40 & 1.13 & 0.85 & 0.96 \\
\hline 341 & Paper and paper products & 0.99 & 1.26 & 1.10 & 1.12 & 1.03 \\
\hline 342 & Printing and publishing & 1.21 & 0.86 & 1.43 & 0.89 & 1.03 \\
\hline 351 & Industrial chemicals & 1.92 & 1.18 & 1.79 & 1.09 & 0.88 \\
\hline 352 & Other chemical products & 1.98 & 0.60 & 0.97 & 0.86 & 0.58 \\
\hline 353 & Petroleum refineries & 1.22 & 1.57 & 3.35 & 0.28 & 0.30 \\
\hline 354 & Coal products & 1.85 & 2.07 & 2.14 & 2.10 & 1.55 \\
\hline 355 & Rubber products & 1.55 & 2.55 & 0.41 & 1.36 & 1.24 \\
\hline 356 & Plastic products & 0.81 & 1.25 & 0.51 & 1.50 & 1.25 \\
\hline 361 & Pottery, china and earthenware & 1.33 & 1.20 & 0.45 & 2.24 & 2.47 \\
\hline 362 & Glass and glass products & 1.91 & 1.92 & 1.67 & 1.57 & 1.60 \\
\hline 369 & Non-metallic mineral products & 2.35 & 1.28 & 1.68 & 1.36 & 1.39 \\
\hline 371 & Iron and steel & 2.54 & 1.97 & 1.33 & 2.82 & 1.54 \\
\hline 372 & Non-ferrous metals & 1.28 & 2.50 & 0.43 & 1.92 & 2.39 \\
\hline 381 & Metal products & 2.07 & 1.78 & 1.22 & 1.79 & 1.39 \\
\hline 382 & Machinery except electrical & 1.91 & 1.12 & 1.31 & 0.75 & 0.72 \\
\hline 383 & Electrical machinery & 2.68 & 1.97 & 0.94 & 0.99 & 1.76 \\
\hline 384 & Transport equipment & 2.00 & 1.33 & 0.76 & 2.07 & 1.81 \\
\hline 385 & Professional and scientific equipment & 1.29 & 1.48 & 1.22 & 3.27 & 3.81 \\
\hline 390 & Other manufacturing industries & 0.52 & 0.76 & 0.92 & 1.26 & 2.19 \\
\hline
\end{tabular}

Source: PADI data base.

a 1970-1995. b 1970-1994.

countries to generate new jobs or even keep up the levels of employment registered at the beginning of the decade. We thus see that during the period from 1990 to 1996 there was a sharp drop in employment, in absolute terms, in Argentina, Brazil, Colombia and Uruguay. In all these cases, it is this decline in manufacturing employment, rather than any significant increase in the physical volume of production, which explains the marked rise in labour productivity in the region in recent years.

Chile, which began its external openness process a good deal earlier than other Latin American countries and, when it did so, registered an increase in the number of bankruptcies of industrial firms and in the levels of open unemployment, represents an exception to this rule because in the 1990s, although it achieved (modest) improvements in labour productivity, these were not at the expense of employment. It might be assumed that this country is at a more advanced stage of its macroeconomic stabilization and structural reform programme, whereas the other countries are still at an earlier stage in the structural adjustment process and are thus suffering a stronger impact of the "destructive" forces described by Schumpeter. According to this line of reasoning, we might assume that when the level of macroeconomic uncertainty prevailing in those societies is reduced, together with a decline in interest rates and an increase in domestic saving and investment, part of the structural unemployment phenomenon will tend to correct itself, even though there will still be a certain degree of structural inability of the manufacturing sector to generate new jobs at the rate demanded by the growth in the economically active population.

After having thus analysed the evolution of labour productivity, in the next section we will set forth an explanatory hypothesis of what happened, involving an evolutionary dynamic of successive phases in the process of stabilization, structural reform and defensive and pro-active investments which occurred over time. The 
intra-sectoral restructuring process, through the entry and exit of firms in the market, and the change in the relative weight of the different branches of industry in manufac- turing as a whole, are central elements in this explanatory hypothesis for the developments registered in the region in this field over the last two decades.

\section{III}

\section{An explanatory hypothesis}

The process we are about to describe consists of at least two different evolutionary dynamics which should be separated and distinguished from each other: on the one hand there is the dynamic inherent in each branch of industry, and on the other there is the dynamic for the structure as a whole. Both of these will be explored in this section. With regard to the first dynamic, it should be noted that the changes in a branch of production over time reflect i) the entry into the market of new enterprises which bring with them new technology; ii) the exit of older and relatively less efficient enterprises from the market, and iii) the improvement of those enterprises which remain in the market, through physical investments, organizational changes and other measures. Thus, in each branch of production, a process of selection takes place which causes some firms to gain ground, others to lose it, and some even to disappear altogether.

With regard to the second dynamic, in addition to the foregoing there is a process of change in the relative weight of the different industrial activities in manufacturing as a whole, which may also be seen as a reflection of the different demand elasticities faced by the various production activities.

In other words, the intra-sectoral selection process among firms in the same line of production and the changes in the relative weight of the different industrial activities over time constitute the two structural components of the evolutionary dynamic we are about to describe. Let us now deal with these two matters separately.

\section{The process of selection among firms within a given branch of production}

Every branch of industry contains firms with different levels of production efficiency. The capital goods and organizational technologies used by different enterprises differ significantly, even between close competitors, thus leading to a very heterogeneous structure of unit production costs and levels of operating profitability within each branch. In practice, these differences are much more important than might be imagined from the standpoint of competitive balance, sometimes reaching ratios of 5:1 or even more.

The reduction in tariffs associated with the external trade openness process and the increase in competition in markets due to the arrival of foreign firms have acted in the present case as an important selection mechanism, obliging local producers to adapt to a new and much more stringent form of competition. Firms have reacted with different degrees of effectiveness to this challenge, or in some cases have not reacted at all, so that many of them have languished even to the point of physically disappearing.

The above patterns of conduct have not been solely the result of the information available to each enterprise and its corresponding reactions but have also been influenced by the morphology and behaviour of the factor markets in which each enterprise has had to operate. The existence of market flaws and imperfect access to longterm finance and the technological know-how needed to carry out major operational changes at the enterprise level are traditional obstacles which help to understand why some firms have carried out successful processes of adaptation and others not, after the recent structural reforms in the Latin American countries.

The existence of imperfect markets and incomplete information undoubtedly presents firms with a much more complex challenge than in the simple models described in conventional textbooks. In a context of asymmetrical information and highly imperfect capital and technology markets, it is not necessarily the most inefficient firms that disappear from the market. On the contrary, it may well be -and indeed the empirical evidence proves this- that in a highly turbulent and uncertain macroeconomic situation enterprises whose strategies concentrate on short-term actions with a high speculative content may have a better chance of surviving the period of structural reforms.

In short, the process we are trying to describe involves a dynamic of change in industrial branches which 
is marked by the entry and exit of firms from the market, hostile takeovers, the relative success of some firms and the failure of others, against a background of market flaws and a dynamic of "creative destruction" which has not so far been addressed very much in the studies on the industrial development of the region.

\section{Changes in the composition of industrial produc- tion}

After having so far dealt with the dynamics of intrasectoral change, we will now turn to the changes in the relative weight of the different branches of industry in the aggregate product.

Let us assume, for the sake of argument, that the manufacturing sector comprises only two such branches of industry. Let us assume, for example, that it consists of one capital-intensive branch processing natural resources and one metal products and machinery branch producing capital goods and consumer goods. In the initial situation, $v$ and $z$ describe the product per person employed and the capital per person in each of the two branches in question, while point $d$ represents the corresponding weighted product. Let us now assume that between $t 0$ and $t l$ the two branches grow at different rates, so that the indicators move to $v$ ' and $z$ ' respectively. The position of point $d$ ' will now depend on how much each branch has grown over its particular trajectory and also on the relative weight of each of them at the end of the period within the aggregate industrial product (figure 1).

When the situation is set forth in this way, it is not hard to see why the macroeconomic stabilization and structural reform programmes of the 1970s and 1980s had a highly differential impact on different sectors of production. The industries processing natural resources had little difficulty in turning over to export activities on

FIGURE 1

Latin America: Changes in the composition of industrial production

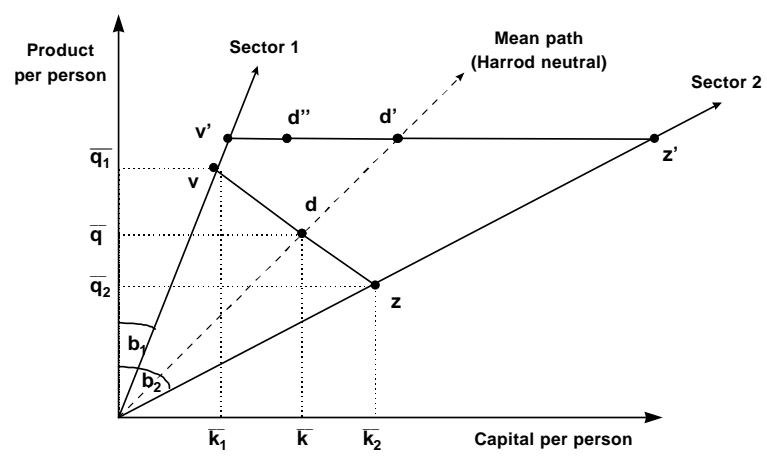

a large scale by replacing their domestic sales with the export to world markets of widely used industrial commodities such as pulp and paper, iron and steel, aluminium, etc. In contrast, however, the branches in the metal products and machinery sector producing capital goods and consumer durables for the domestic market were simultaneously faced with a sharp drop in that market and a growing inflow of imported substitutes which now flooded local markets as a result of the reduction of tariffs. This has been the situation which has prevailed in the first phase of the external openness process in countries such as Argentina, Brazil, Chile and others, where local capital goods and consumer durables producers have had to simultaneously cope with a drop in domestic demand and a massive inflow of imported substitutes. It is this situation which leads, at the completion of the openness process, to a structure of production which is much more devoted to the processing of natural resources and is less specialized in the production of capital goods and consumer durables for the domestic market.

If we now take both these phenomena together that is to say, on the one hand the intra-sectoral changes associated with the different capacities of adaptation of the firms in a given branch, and on the other the different rates of expansion of the branches as a function of the elasticity of demand and the growth rates they have achieved- we can visualize a complex evolutionary dynamic in which the macroeconomic, meso-economic and microeconomic aspects act together to condition the planning horizon of firms, their degree of uncertainty about the future, the regulatory framework, the demand conditions in which they operate, their access to factor markets, their real perception of what is going on in their economic and social environment, and the various flaws in the factor markets they must use. This interaction between the macroeconomic, meso-economic and microeconomic aspects in a context of macroeconomic turbulence and extremely imperfect production factor markets underlies the macroeconomic stabilization and structural reform programmes carried out in recent years in the countries of the region.

Each industrial branch and each firm metabolizes the changes in the system of incentives in a different way, as a function of its past history, its incomplete perception of what is going on, and its (imperfect) capacity to adapt to the new circumstances. Although the empirical information available on the above-mentioned set of variables is only fragmentary and is extremely dispersed, we will nevertheless try to present in the following pages various items of information which will help to reconstruct an evolutionary situation of the type described here. 


\section{IV}

\section{The empirical evidence}

\section{Intra-sectoral restructuring: the entry and exit of firms from the market}

The available data show that the external openness processes have been accompanied, on the one hand, by an increase in the rate of disappearance of firms, and on the other, by the entry of new firms into the market which have brought with them more modern technologies which are a clear improvement on the average technological practices which had previously prevailed in the industries in question.

In Chile, the opening-up of the economy in the 1970s was associated with a marked increase in the rate of closure of firms. It is calculated that over 4,000 firms left the market between the second half of that decade and the early 1990s, especially in such branches of industry as textiles, clothing, footwear, and metal products and machinery industries such as consumer durables and capital goods (figure 2). These closures of firms were particularly numerous among medium-sized enterprises (by Chilean standards), but did not hit the smaller and larger firms so hard (Mizala, 1992). The few studies available on this subject show that the closures of firms were not necessarily connected with indicators of operational efficiency: in a highly turbulent and uncertain macroeconomic situation speculative forms of conduct tended to prevail over attempts to rationalize production, so that the business successes or failures were not due to the presence or absence of organizational or technological excellence but, in many cases, to speculative forms of conduct on the financial level.

FIGURE 2

Chile: Failures of industrial firms

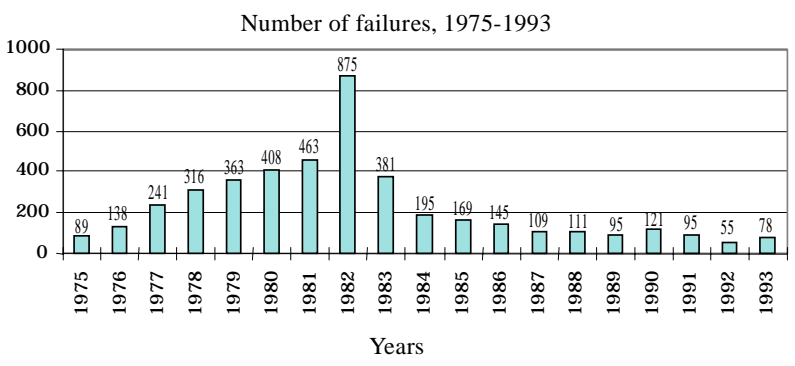

Source: A. Mizala, 1992.
With regard to the entry of firms into the market, it is interesting to note, for example, that the restructuring of the vegetable oils industry in Argentina was associated with the entry of a new generation of production facilities of much larger scale and higher capital density per worker, where labour productivity was practically double that of the typical plants of the 1970s (table 4). The industry is moving towards production processes of a chemical nature in which the technological and organizational know-how is very different from that of the old edible oil industry which existed in the country before. The changes are to be seen not only in the production technology used but also in the institutional base and system of competition prevailing in this branch. New actors and new forms of vertical integration both within the industry and towards collateral branches (transport, port silos, docks) form part of the sectoral restructuring process in this case (De Obschatko, 1996). Several sectoral studies reveal similar patterns of disappearance and creation of jobs (Katz, 2000 and Katz (forthcoming)).

In short, the empirical evidence strongly confirms the idea that the industrial restructuring process we are describing here is associated with the exit from the market of "marginal" firms (although in this case marginal does not necessarily mean more inefficient) and the entry of a new generation of industrial establishments closer to the general international level of the industry in question. These, by necessity, are much more capital-intensive, more labour-saving and more internationally competitive than the generation of industrial plants they are replacing.

\section{Changes in the relative weight of the different industrial branches}

As already noted in the introduction to this article, there has been an increase over time in the relative weight of the industrial branches which process natural resources (table 5). This can be clearly seen from the table in question, which also shows how the group of traditional industries (footwear, clothing, wood products, furniture, textiles, printing, etc.) have contracted and lost ground in relative terms between 1970 and 1996. Finally, in the metal products and machinery branches we considered 
TABLE 4

Argentina: Number of plants, employment and labour productivity in the Argentine vegetable oils industry, 1973-1974 and 1993-1994

\begin{tabular}{lccccc}
\hline Year & $\begin{array}{c}\text { Number } \\
\text { of plants }\end{array}$ & $\begin{array}{c}\text { Number } \\
\text { of employees }\end{array}$ & $\begin{array}{c}\text { Volume of } \\
\text { production } \\
\text { (thousands } \\
\text { of tons) }\end{array}$ & $\begin{array}{c}\text { Output } \\
\text { per plant } \\
\text { (thousands } \\
\text { of tons) }\end{array}$ & $\begin{array}{c}\text { Output per } \\
\text { worker } \\
\text { (tons) }\end{array}$ \\
\hline $1973-1974$ & 67 & 6895 & 1740 & 26 & 252 \\
$1993-1994$ & 59 & 4943 & 12220 & 207 & 2472 \\
\hline
\end{tabular}

Source: De Obschatko (1996).

it necessary to separate the motor industry (which received special treatment in industrial policy) from the rest of the industries producing consumer durables and capital goods. In the case of the latter, the contraction or stagnation associated with the increased openness to external trade can clearly be seen in the various cases analysed. However, the rapid expansion of the motor industry in Argentina, Brazil, Colombia and Mexico in the 1990s more than offset the contraction in the rest of the metal products and machinery branch.

\section{The labour productivity gap and employment}

Table 6 shows the relation between the relative labour productivity gap and employment in Argentina, Chile and Mexico. The blocks refer respectively to three-digit ISIC industrial branches which have reduced the relative labour productivity gap with the United States or have lost ground in that respect and at the same time have reduced or increased their level of employment. Weighing the various industrial sectors by their relative share in the industrial product at the end of the period studied, we see that in Argentina, for example, $70 \%$ of industry is located in the sub-group of branches which have gradually come closer to average United States pro- ductivity but have reduced their levels of employment in absolute terms. Only $20 \%$ of industry narrowed the relative gap with United States productivity yet at the same time generated additional jobs.

In contrast, in the case of Chile $12 \%$ of its manufacturing industry narrowed the productivity gap while reducing employment levels, but $33 \%$ did so in an expansionary manner which generated additional jobs. This undoubtedly reflects the markedly different structural characteristics between the two industrial restructuring processes. As suggested in earlier pages, it may be supposed that the differences between the two cases may be explained by the different phases of the macroeconomic adjustment process that the countries in question were passing through, with the Chilean case representing a situation of greater stability at the aggregate level in which fresh investment played a more significant role than in the case of Argentina.

The Mexican case would appear to come midway between these two situations. In Mexico, $37 \%$ of its industry narrowed the relative labour productivity gap with the United States while simultaneously generating new jobs, while $30 \%$ did so through restructuring processes which reduced the level of employment. Undoubtedly the assembly industries have acted as generators of fresh employment, whereas there have been dismissals of employees in the non-assembly sectors of Mexican industry.

The Argentine case is the most extreme of the three. In the last section of this article, when we examine some of the new structural problems that the region has to face as a result of the industrial restructuring process, we will show how the greater difficulty of the new industrial structure in generating new jobs is one of the main items on the new agenda of public policy issues that the governments of the region must now deal with.

TABLE 5

Latin America (five countries): Changes over time in the relative weight of the different industrial branches in the global manufacturing product

\begin{tabular}{|c|c|c|c|c|c|c|c|c|c|c|c|c|c|c|c|}
\hline & \multicolumn{3}{|c|}{ Argentina } & \multicolumn{3}{|c|}{ Brazil } & \multicolumn{3}{|c|}{ Chile } & \multicolumn{3}{|c|}{ Colombia } & \multicolumn{3}{|c|}{ Mexico } \\
\hline & 1970 & 1990 & 1996 & 1970 & 1990 & 1996 & 1970 & 1990 & 1996 & 1970 & 1990 & 1996 & 1970 & 1990 & 1996 \\
\hline $\mathrm{I}^{\mathrm{a}}$ & 15.6 & 14.3 & 13.1 & 18.8 & 22.9 & 22.8 & 14.9 & 10.1 & 10.2 & 10.7 & 9.6 & 10.5 & 13.3 & 12.3 & 13.9 \\
\hline $\mathrm{II}^{\mathrm{b}}$ & 9.9 & 8.5 & 12.1 & 9.9 & 7.0 & 8.7 & 7.7 & 2.3 & 2.0 & 2.9 & 4.3 & 6.5 & 5.5 & 9.5 & 10.8 \\
\hline $\mathrm{III}+\mathrm{IV}^{\mathrm{c}}$ & 36.2 & 46.7 & 45.7 & 35.8 & 39.6 & 42.4 & 43.2 & 55.5 & 56.2 & 45.7 & 51.1 & 51.2 & 46.8 & 46.8 & 46.5 \\
\hline $\mathrm{V}^{\mathrm{d}}$ & 38.2 & 30.5 & 29.0 & 35.5 & 30.5 & 26.1 & 34.2 & 32.0 & 31.6 & 40.7 & 34.9 & 31.8 & 34.4 & 31.4 & 28.8 \\
\hline
\end{tabular}

${ }^{a}$ Metal products and machinery industry, excluding the motor industry (ISIC groups 381, 382, 383, 385).

b Transport equipment (ISIC group 384).

c Foodstuffs, beverages and tobacco (ISIC groups 311, 313, 314) plus industries processing natural resources (ISIC groups 341, 351, 354, 355, $356,371,372$ ), excluding group 372 in the case of Chile.

${ }^{\mathrm{d}}$ Traditional labour-intensive industries (ISIC groups 321, 322, 323, 324, 331, 332, 342, 352, 361, 362, 369, 390). 
TABLE 6

Argentina, Chile and Mexico: Relative labour productivity gap and absorption of labour, 1970-1996

A. Argentina

\begin{tabular}{|c|c|c|c|c|}
\hline \multirow[b]{2}{*}{ 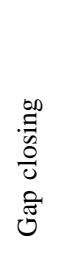 } & Employment increased & \multicolumn{3}{|c|}{ Employment reduced } \\
\hline & $\begin{array}{l}353 \\
355 \\
371\end{array}$ & $\begin{array}{l}311 \\
321 \\
332 \\
342 \\
351 \\
352\end{array}$ & $\begin{array}{l}354 \\
362 \\
369 \\
372 \\
381 \\
382\end{array}$ & $\begin{array}{l}383 \\
384 \\
385\end{array}$ \\
\hline 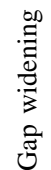 & $\begin{array}{l}313 \\
323 \\
324\end{array}$ & $\begin{array}{l}314 \\
322 \\
331 \\
341\end{array}$ & $\begin{array}{l}356 \\
361 \\
390\end{array}$ & \\
\hline
\end{tabular}

B. Chile

\begin{tabular}{|c|c|c|c|}
\hline & Employment increased & & oyment reduced \\
\hline 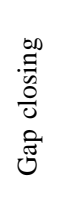 & $\begin{array}{l}331 \\
341 \\
369 \\
371 \\
372 \\
381\end{array}$ & $\begin{array}{l}342 \\
351 \\
353 \\
362\end{array}$ & \\
\hline 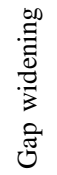 & $\begin{array}{l}313 \\
323 \\
324\end{array}$ & $\begin{array}{l}314 \\
321 \\
355 \\
382 \\
383\end{array}$ & $\begin{array}{l}384 \\
385 \\
390\end{array}$ \\
\hline
\end{tabular}

C. Mexico

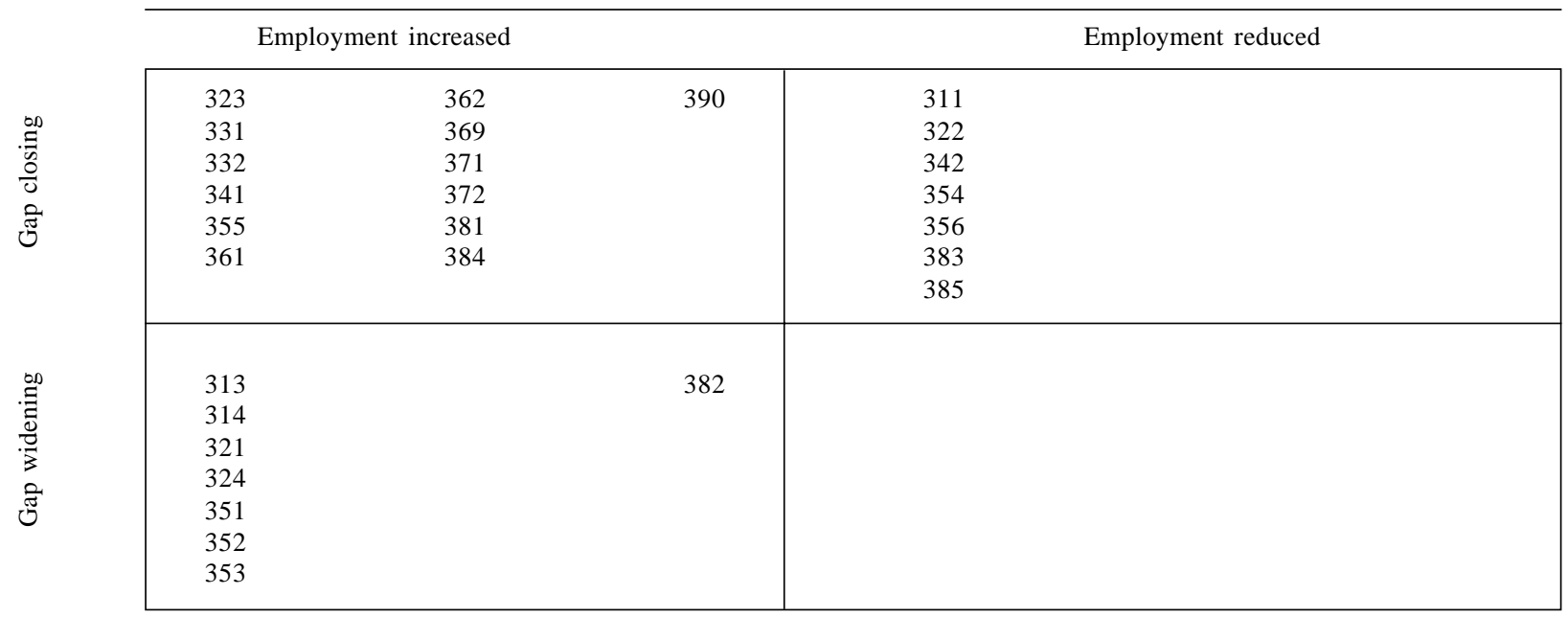

Source: PADI data base of the ECLAC Division of Production, Productivity and Management. 
Now that we have analysed various pieces of empirical evidence which complement our overview of the industrial restructuring process taking shape in Latin America, the final pages of this article will seek to give a broad picture of the situation and make a general assess-

\section{V}

\section{Final reflections}

This study seeks to make some progress towards the construction of a micro/macro explanatory hypothesis for the complex restructuring process currently being undergone by Latin American industry. The way in which the interplay between the macro, meso and micro levels conditions the growth path and structural transformation process of each industrial branch and industry as a whole has been little explored by economists and undoubtedly requires more work in terms of conceptualization and study. In this last section we will briefly address both these matters.

\section{Some features of the micro/macro context un- derlying the industrial restructuring process in the region}

We will begin by assuming that the conduct of firms in investment matters depends primarily, though not exclusively, on the opportunities and risks as perceived by each entrepreneur. This perception shapes their profit expectations and conditions their propensity to invest. We will assume, then, that it is the pursuit of profits (or avoidance of the loss of previous gains) which causes entrepreneurs to act, "defending" prior investments if this is economically feasible and/or embarking on new investment projects which will expand the production capacity they control.

In a simple balanced competition model, three factors would influence the decisions of this type of entrepreneur: i) the present and expected future price of the product manufactured, ii) the present and expected future prices of the production factors needed for this, and iii) the amounts of factors needed per unit of production (in the light of the available technology).

Let us first consider a simplified situation: the firm manufactures a single homogeneous product, there are no imported substitutes, the factor markets are "well behaved", the firm possesses the necessary technology, ment of possible weak points in the present industrialization model which make its long-term sustainability open to question. Employment and the foreign trade balance would appear to be the weakest points in this respect and are worthy of detailed analysis. and there is no macroeconomic uncertainty, as the economy operates in conditions of external and fiscal equilibrium. How does the replacement of an old plant with a new one take place in this type of context? In other words, what is the conceptual model based on conventional price theory that economists use to explain how to determine the optimum rate of births and deaths of firms and the replacement of one production technique by another one which is better (that is to say, one which can produce the same good at a lower unit cost)?

In the experimental conditions thus assumed, it is the market price of the product and the factor prices, together with the savings on factor use made possible by the new technologies, which determine the optimum rate of replacement of old plants and technologies by new ones. The arrival of a new firm (or a new technology) causes the market price of the product in question to go down, and when one of the existing firms is unable to cover its variable production costs with the sale price of its products it must necessarily leave the market.

Let us now consider how this stylized model of microeconomic behaviour would be affected if we admit the existence of factor market flaws, incomplete information available to the firm, volatility of the macroeconomic variables, and a specific regulatory and institutional framework for each sector which of itself affects the conduct of the entrepreneurs in addition to the possible effect of the economic variables. This exercise allows us to take account in our analysis of the effect that increased openness, deregulation and privatization have had on microeconomic conduct and on the restructuring path that Latin American industry has been following, in a context of market flaws and imperfect availability of information for the firms.

Casual observation suggests that there is a first period -which we will call Phase I of the macroeconomic stabilization and structural reform programme-in which there is, among other things: i) exchange rate devalua- 
tion, ii) rises in real interest rates, iii) a decline in the level of tariff protection, iv) a contraction in real wages, and v) elimination of price controls. All this involves a change in the structure of the "main" prices in the economy, with the ultimate objective of reducing the domestic absorption of goods and services in order to make it possible to achieve a new state of external and fiscal equilibrium. From the point of view of the individual firms, the above changes take the form of shifts and turns in their cost and demand curves (Katz and Vera, 1997) because, among other things, of declines in the import prices of goods that can take the place of those that they produce themselves, lower prices of the capital goods they use in their production, reductions in the real wages they have to pay their workers, and changes in the rates of interest they have to pay on their working capital. As well as taking account of these phenomena, which are due primarily to changes in the overall system of macroeconomic incentives prevailing in the society in question, entrepreneurs must also take account of data of a strictly sectoral nature which may or may not substantially alter the institutional context, in addition to changes in the macroeconomic variables. The strictly sectoral context is affected by such variables as the special tariff treatment that each sector may receive (as in the case of the motor industry, for example), promotional subsidies for particular geographical locations, rights of ownership of natural resources, export credits and insurance, etc.

The interaction between the macroeconomic and the sectoral levels means that, even when there is a generalized decline in aggregate investment, there may nevertheless be significant increases in investments in particular branches of industry, if strictly sectoral forces justify this.

The above changes set in motion a complex dynamic of death and disappearance of firms, takeovers, and the entry of new producers into the market. Business profit calculations are radically altered by the changes in relative prices and the fall in domestic demand (and increase in external demand) as a result of exchange rate devaluation. The increase in macroeconomic turbulence normally observed in Phase I of the stabilization programme means that the planning horizon of enterprises tends to be shortened and short-term investments tend to prevail over those connected with production and technology.

Not all macroeconomic stabilization programmes manage to restore the fiscal and external balance of the economy. When they do, the stabilization episode puts the economy on a new path of external and fiscal equilibrium, with a new structure of relative prices and income distribution, so that the country can enter on what we may call Phase II of the stabilization programme, in which there may be a gradual reduction in real interest rates, revitalization of domestic demand and a rise in the growth rate of the economy.

In many cases, however, the programmes are not successful in stabilizing the economy, and the adjustment programme fails to reduce the imbalance prevailing at the macroeconomic level. In such an event, the macroeconomic turbulence tends to get worse, most seriously affecting the behaviour of the individual economic actors. The imbalance in the public accounts increases, as does the State deficit, and unless external financial support is obtained in order to stabilize the fiscal accounts the government is obliged to resort to domestic indebtedness, thus further increasing the already high real interest rates prevailing in the economy and leading to an even greater contraction in the level of activity than that due to the initial adjustment.

In all cases, however, it is clear that the change in the system of macroeconomic incentives affects the profit calculations of each firm, thus setting in motion an intrasectoral restructuring process of the type described earlier.

In Phase I, in line with the changes in the system of macroeconomic policies, first of all domestic demand contracts and somewhat later-since it is necessary to establish the necessary import channels- imported substitutes arrive on the domestic market at lower local prices than many domestic firms are able to offer. Some of the latter are thus faced with imminent physical disappearance: an effect which is further accentuated by the tariff reductions that also form part of the macroeconomic stabilization programme.

In Phase II, under the structural adjustment programme, domestic interest rates tend to go down and domestic demand and public and private investment gradually recover, thus improving the potential profitability of investing in new installed capacity. New production plants thus appear which use more modern technology and are more capital-intensive.

It may be intuitively perceived that during the sequence in question two processes are simultaneously at work -an intra-sectoral restructuring process and another of an inter-sectoral nature- and resources move to the activities with the highest rates of profitability in the new relative price structure that prevails in the economy. Industrial sectors making intensive use of natural resources tend to gain ground, since they are engaged primarily in export activities and are benefited by the exchange rate devaluation. In addition, some other industrial branches also gain ground because they have managed to obtain 
special treatment under the prevailing economic policy and thus do not have to adapt to the general conditions of greater external trade openness. The economy thus moves in the direction of greater capital-intensity in the various production activities and greater incorporation of labour-saving technologies.

The empirical information presented earlier suggests that over the last two decades the region has indeed gone through a process of intra-sectoral and inter-sectoral change of this type. Some firms have disappeared, while other new firms have entered the market which are much more capital-intensive and are closer to the international "state of the art". The production structure has tended to move towards the exploitation of natural comparative advantages, and sectors which enjoy relatively privileged regulatory frameworks (the motor industry) or non-tradeable service activities have managed to maintain or even increase their relative shares of the manufacturing product.

Can this process of restructuring and modernization of production be maintained over time? There are two points which stand out in this respect and give rise to some doubts as to whether the answer to this question can be affirmative. The first is the capacity of the industrial sector to generate new jobs at the rate demanded by the growth of the economically active population; the second is the endemic deterioration of the external trade balance, which seems to be associated with the new structure of production and the pattern of specialization in international trade that the countries of the region have been adopting. In both these cases there are serious grounds for doubt regarding the answer.

\section{Employment and the external trade balance: two weak points in the present Latin American in- dustrial development model}

\section{a) The low rate of absorption of labour}

The stylized facts analysed earlier in this article clearly show that one of the main problems in the new industrialization model is its low capacity to generate employment. Although it is true that this problem is to some extent exaggerated, because subcontracting and the new tendencies towards less vertical integration of production processes give rather a false idea of the true effects of the labour-saving aspects of the new technologies in organization of labour, there can be no doubt that computerized production, based on numerical control and "real time" operation of production facilities, does lead to the elimination of production line workers and administrative personnel previously employed in the planning and organization of work.
This is also furthered by the relatively lower cost of capital goods and the rapid spread of information technology, which explain the growing use in recent years of computers, data transmission equipment, etc.

In line with the explanatory hypothesis presented earlier in this article, it could be concluded that the trend towards less use of labour would tend to be concentrated in Phase I of the macroeconomic stabilization and structural reform programmes, whereas in Phase II -with the increase in the rate of domestic saving, the revitalization of business ventures and the appearance of many new investments- there should be a renewed tendency towards increased demand for labour, especially in the case of human resources skilled in computer-based production technologies.

It would appear to be this process of successful macroeconomic stabilization and the renewed spirit of enterprise among entrepreneurs which enabled the Chilean economy to overcome the high indices of unemployment and closure of factories registered in the second half of the 1970s and first half of the 1980s. This reading of the process suggests the existence of endogenous micro/macro forces capable of partly correcting the structural unemployment phenomena associated with Phase I of the new technological paradigm being experienced by the countries of the region. These forces, however, only seem to operate in the long term, and only when there are sustained successes in terms of macroeconomic stability and recovery of growth and investment rates.

Another problem which is a source of concern is connected with the growing manufacturing trade deficit registered by the countries of the region.

\section{b) Towards a chronic trade deficit?}

We will now deal with some points of interest regarding the external trade balance for industrial products (table 7). The data show, first, that the negative external trade balance has been growing over time, and second, that this is closely connected with the industrial restructuring process and the new form of insertion in international trade which became established in the 1990s. The negative trade balances tend to accumulate in the metal products and machinery branches producing capital goods, agricultural machinery, consumer durables and scientific instruments (in table 7 these appear as Group I). More recently, negative balances have also begun to be registered in the Group II branches engaged in the production of vehicles and transport equipment. After having registered positive trade balances in Brazil and Mexico in the early 1990s, the recent import boom has 
TABLE 7

Latin America (six countries): Trade balance of industrial branch groups I, II, III, IV and Va

(Gross value of total production of manufactures, in millions of current dollars)

\begin{tabular}{|c|c|c|c|c|c|c|c|c|}
\hline \multirow[b]{2}{*}{ Group } & \multicolumn{4}{|c|}{ Argentina } & \multicolumn{4}{|c|}{ Brazil } \\
\hline & 1970 & 1974 & 1990 & 1996 & 1970 & 1974 & 1990 & 1995 \\
\hline I & -451.7 & -411.0 & -631.6 & -7545.6 & -815.5 & -2797.1 & -2589.0 & -10463.6 \\
\hline II & -68.2 & -6.0 & -18.2 & -1842.4 & -235.6 & -432.4 & 1641.2 & -3017. \\
\hline I+II & -519.9 & -417.0 & -649.8 & -9388.0 & -1051.2 & -3229.4 & -947.9 & -13481.6 \\
\hline III & 759.2 & 1243.7 & 3833.4 & 6084.5 & 1330.2 & 2996.0 & 4089.3 & 5192. \\
\hline IV & -543.9 & -1269.7 & 610.4 & -3286.9 & -622.9 & -4385.2 & 4000.7 & 1556.7 \\
\hline III+IV & 215.4 & -26.0 & 4443.8 & 2797.6 & 707.3 & -1389.2 & 8090.1 & 6749.3 \\
\hline $\mathrm{V}$ & -77.9 & -39.8 & 798.4 & -899.0 & 52.7 & 432.7 & 2110.3 & 866.6 \\
\hline Net balance & -382.4 & -482.8 & 4592.4 & -7489.4 & -291.1 & -4185.9 & 9252.5 & -5865.6 \\
\hline Gross value of production & 8660.7 & 45677.5 & 79949.1 & 129800.6 & 25903.2 & 68074.7 & 238719.3 & 202622.6 \\
\hline $\begin{array}{l}\text { Net balance/gross value } \\
\text { of production }(\%)\end{array}$ & -4.4 & -1.1 & 5.7 & -5.8 & -1.1 & -6.1 & 3.9 & -2.5 \\
\hline
\end{tabular}

\begin{tabular}{|c|c|c|c|c|c|c|c|c|}
\hline \multirow[b]{2}{*}{ Group } & \multicolumn{4}{|c|}{ Chile } & \multicolumn{4}{|c|}{ Colombia } \\
\hline & 1970 & 1974 & 1990 & 1996 & 1970 & 1974 & 1990 & 1996 \\
\hline I & -320.4 & -351.6 & -2625.8 & -5300.5 & -260.8 & -333.1 & -1689.6 & -3250.8 \\
\hline II & -117.4 & -128.0 & -646.4 & -2166.2 & -158.8 & -179.5 & -516.1 & -1077.4 \\
\hline $\mathrm{I}+\mathrm{II}$ & -437.7 & -479.5 & -3272.3 & -7466.7 & -419.6 & -512.6 & -2205.7 & -4328.3 \\
\hline III & -33.2 & -220.4 & 601.0 & 1248.5 & -0.1 & 56.6 & 135.7 & -170.9 \\
\hline IV & 848.8 & 1673.4 & 3297.6 & 3726.2 & -222.9 & -548.4 & -1502.8 & -1751.6 \\
\hline III+IV & 815.6 & 1453.0 & 3898.6 & 4974.7 & -223.0 & -491.9 & -1367.1 & -1922.5 \\
\hline V & -70.4 & -93.4 & -284.6 & -1449.5 & -35.3 & 138.1 & 761.9 & 56.7 \\
\hline Net balance & 307.4 & 880.0 & 341.8 & -3941.5 & -677.9 & -866.3 & -2810.8 & -6194.0 \\
\hline Gross value of production & 2416.7 & 3440.0 & 15133.8 & 23768.3 & 3505.7 & 7011.5 & 21013.8 & 33161.7 \\
\hline \multirow[t]{2}{*}{$\begin{array}{l}\text { Net balance/gross value } \\
\text { of production }(\%)\end{array}$} & 12.7 & 25.6 & 2.3 & -16.6 & -19.3 & -12.4 & -13.4 & -18.7 \\
\hline & \multicolumn{4}{|c|}{ Mexico } & \multicolumn{4}{|c|}{ Uruguay } \\
\hline Group & 1970 & 1974 & 1990 & 1994 & 1970 & 1974 & 1990 & 1995 \\
\hline I & -812.1 & -1395.8 & -7202.6 & -7655.8 & -47.0 & -40.5 & -329.1 & -700.9 \\
\hline II & -389.8 & -712.2 & 402.5 & -391.7 & -28.8 & -23.5 & -107.9 & -273.9 \\
\hline $\mathrm{I}+\mathrm{II}$ & -1201.9 & -2108.1 & -6800.1 & -8047.4 & -75.8 & -64.0 & -437.0 & -974.9 \\
\hline III & 208.1 & 253.1 & -1913.7 & -2482.4 & 93.1 & 163.2 & 503.5 & 448.2 \\
\hline IV & -333.8 & -982.6 & -1935.3 & -8910.0 & -54.4 & -118.7 & -221.0 & -406.7 \\
\hline III+IV & -125.7 & -729.5 & -3849.0 & -11392.4 & 38.6 & 44.5 & 282.5 & 41.5 \\
\hline V & -85.0 & 67.2 & -1201.1 & -3250.5 & 50.8 & 64.2 & 537.7 & 252.6 \\
\hline Net balance & -1412.7 & -2770.4 & -11850.2 & -22690.3 & 13.6 & 44.7 & 383.1 & -680.8 \\
\hline Gross value of production & 21947.8 & 45312.5 & 128234.0 & 178528.6 & 1381.3 & 3862.9 & 10031.7 & 8564.0 \\
\hline $\begin{array}{l}\text { Net balance/gross value } \\
\text { of production }(\%)\end{array}$ & -6.4 & -6.1 & -9.2 & -12.7 & 1.0 & 1.2 & 3.8 & -7.9 \\
\hline
\end{tabular}

Source: PADI data base of the ECLAC Division of Production, Productivity and Management.

a Groups: I = metal products and machinery; II = vehicles and transport equipment; III = foodstuffs; IV = widely used industrial commodities; V = labour-intensive goods.

turned the balance into a heavy deficit. In Argentina and Colombia it was never possible to reverse the negative trade balance, in spite of the expansion of the sector in recent years and the improvement in relative productivity achieved by it in the 1990s.

On the other hand, it may be seen from table 7 that in the case of Argentina, Uruguay, Chile and Brazil, which are important exporters of foodstuffs to markets inside and outside the region, positive trade balances tend to build up in the branches making up Group III. Colombia, however, and even more so Mexico are net importers of food. Finally, in Group IV, Chile and Brazil have net trade surpluses in the field of widely used industrial commodities. 
Taking into account the systematic nature of the situation described, we may assert in conclusion that the new industrialization model involves a clear pattern of production specialization and international insertion in the fields of the processing of natural resources and the production of foodstuffs and industrial commodities with little local value added, while the model also involves growing dependence on the exterior in the fields of production machinery and equipment, scientific instruments and capital goods in general. Although decades have passed since ECLAC drew attention to the possible fragility of a pattern of production specialization and international insertion of this type, and although we know today that the production of both foodstuffs and industrial commodities can incorporate on a large scale the new technologies arising in such fields as genetics, biotech- nology and mineralogy, the long-term pattern that seems to exist behind the figures presented here raises serious doubts about the possibility that the economies of the region can maintain an external balance when their industrial activities register growing trade deficits in the fields of metal products and machinery and capital goods.

Will this be a new Achilles' Heel that production and technological development policies will have to deal with in the medium and long term? All that we can say is that so far this problem has received little attention, and a new, forward-looking debate is needed if we are to gain a better understanding of the long-term sustainability of the external trade openness and economic deregulation programmes undertaken in recent years by a number of countries of the region.

(Original: Spanish)

\section{Bibliography}

Barro, R. J. and X. Sala-i-Martin (1995): Economic Growth, New York, McGraw-Hill.

Beckerman, W. (1975): The British Economy in 1975, London, The National Institute of Economic and Social Research.

De Obschatko, E. (1996): Industrialización basada en recursos naturales, Santiago, Chile, Economic Commission for Latin America and the Caribbean (ECLAC), mimeo.

Dosi, G. (ed.) (1988): Technical Change and Economic Theory, London, Pinter Publishers.

Freeman, C. (1994): The economics of technical change, Cambridge Journal of Economics, vol. 18, No. 5, Cambridge, Massachusetts, Academic Press Limited.

Guadagni, A. (1997): Panorama actual de la economía argentina, Colección Temas Económicos y Sociales, Buenos Aires, Fundación Omega Seguros.

Kaldor, N. (1966): Causes of the Slow Rate of Growth in the United Kingdom, London, Cambridge University Press.

Katz, J. (1969): Production Functions, Foreign Investment and Growth, Amsterdam, The Netherlands, North-Holland Publishing Company.

(1997): Cambios en la estructura y comportamiento del aparato productivo latinoamericano en los años 1990: después del Consenso de Washington ¿Qué?, "Desarrollo Productivo" series, No. 65, Santiago, Chile, ECLAC.

(2000): Reformas estructurales, "regímenes sectoriales” y desempeño industrial de América Latina en los años 1990, Santiago, Chile, ECLAC/IDRC.

(forthcoming): Reformas estructurales, productividad y conducta tecnológica, Santiago, Chile, ECLAC/Fondo de Cultura Económica.

Katz, J., J. M. Benavente, G. Crespi and G. Stumpo (1997): New problems and opportunities for industrial development in Latin America, Oxford Development Studies, vol. 25, No. 3, Oxford, U.K.

Katz, J. and B. Kosacoff. (1989): El proceso de industrialización en la Argentina. Evolución, retroceso y perspectiva, Buenos Aires, ECLAC Office in Buenos Aires.
(1998): Aprendizaje tecnológico, desarrollo institucional y la microeconomía de la sustitución de importaciones, Desarrollo económico, vol. 37, No. 148, Buenos Aires, Instituto de Desarrollo Económico (IDES).

Katz, J. and H. Vera. (1997): The ongoing history of a Chilean metal products and machinery firm, CEPAL Review, No. 63, LC/G.1986-P, Santiago, Chile, ECLAC.

Metcalfe, J.S. (1997): Innovation systems and endogenous growth theory, Manchester, U.K., November, mimeo.

Mizala, A. (1992): Las reformas económicas de los años setenta y la industria manufacturera chilena, Colección Estudios CIEPLAN, No. 35, Santiago, Chile, Economic Research Corporation for Latin America (CIEPLAN).

Nelson, R. and S. Winter (1982): An Evolutionary Theory of Economic Change, Cambridge, Massachusetts, Cambridge University Press.

Nelson, R. (1991): Why do firms differ, and how does it matter?, Strategic Management Journal, vol. 12.

(1997): How new is new growth theory?, Challenge, vol. 40, No. 5, New York, M.E. Sharpe, Inc.

Rommer, P. (1986): Increasing returns and long-run growth, Journal of Political Economy, vol. 94, No. 5, Chicago, Illinois, University of Chicago Press.

(1992): Two strategies for economic development: Using ideas and producing ideas, Proceedings of the World Bank Annual Conference on Development Economics, 1992, Washington, D.C., World Bank.

Salter, G.W. (1960): Productivity and Technical Change, London, Cambridge University Press.

Solow, R. (1957): Technical change and the aggregate production function, Review of Economics and Statistics, vol. 39, No. 3, Cambridge, Massachusetts, Harvard University Press.

(1988): Growth theory and after, The American Economic Review, vol. 78, No. 3, Washington, D.C., American Economic Association, June. 